\title{
Evaluation of Pattern Quality by Analyzing Signal of Patterned Media Fabricated by Nitrogen Ion Implantation
}

\author{
Tatsuya Hinoue, Kenichi Ito, Yoshiyuki Hirayama, and Yuzuru Hosoe \\ Central Research Laboratory, Hitachi Ltd., 2880 Kozu, Odawara, 256-8510, Japan
}

\begin{abstract}
Patterned media were fabricated by nitrogen ion implantation and changes of the pattern quality with ion energy were evaluated by analyzing the readback signals. The ion energies were $8,12,14$ and $16 \mathrm{keV}$, and the dosage was $2.5 \times 10^{16}$ ions $/ \mathrm{cm}^{2}$. Auto correlation signal to noise ratio of DC-magnetized preamble pattern was maximized at $12 \mathrm{keV}$, though the saturation magnetization of the ion-implanted area was decreased as the ion energy increased throughout the range from $8 \mathrm{keV}$ to $16 \mathrm{keV}$. 2D-maps of the signal amplitude showed larger fluctuation of the pattern shape for the ion energy of $16 \mathrm{keV}$ than for the ion energy of $8 \mathrm{keV}$. The standard deviations of the pattern width were $4.3 \mathrm{~nm}$ and $8.4 \mathrm{~nm}$ for $8 \mathrm{keV}$ and $16 \mathrm{keV}$, respectively, which were almost the same values as the standard deviations of calculated ion lateral distribution. The results indicate that some ions distributed under the mask by the ion lateral straggling and thus affected the pattern quality. For high quality patterning, ion lateral straggling needs to be suppressed by lowering ion energy.
\end{abstract}

Key words: patterned media, ion implantation, nitrogen, ion energy, readback signal

\section{窒素イオン注入により作製したパタン媒体の再生信号解析による パタン品質の評価}

\author{
檜上竜也 ${ }^{* 1} \cdot$ 伊藤健一 ${ }^{* 1}$ ・平山義幸・細江譲*1 \\ 日立製作所中央研究所，小田原市国府津 2880（率256-8510）
}

\section{1. はじめに}

将来の高密度記録を可能とするパタン媒体の作製技術として, イオン注入を用いた方法が注目されている，この方法では，非磁 性イオンをビットやトラックの間に注入してこれらを磁気的に分 離することで，媒体表面の平坦性を維持したままパタン媒体を作 製できる1)-16).イオン注入を用いて作製したパタンの信号をへッド を浮上させて再生した例が報告されており 9)-15), イオン注入による 方法が磁気的なパタンの作製と安定したヘッド浮上性が得られる 平坦な表面の両立に適していることが示された。

本研究では, 窒素イオンをパターニングに用いた．窒素イオン 注入はこれまでに $\mathrm{CoCrPt}$ 合金 ${ }^{10), 12), 15),} \mathrm{Co} / \mathrm{Pd}$ および $\mathrm{Co} / \mathrm{Pt}$ 多層

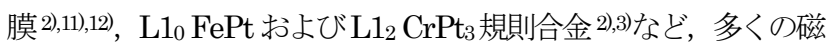
性膜のパターニングに有効であることが報告されている。我々は 窒素イオン注入によりパタン媒体を作製し，イオンを注入した部 分の磁化を低減することがパタンの品質を向上する上で重要であ ることを以前報告した ${ }^{15)}$. 一方，注入されたイオンの分布はイオ ンエネルギーにより変化するため, パタンの品質はパターニング 時のイオンエネルギーによっても異なってくると考えられる. 本 研究では，イオンエネルギーを変えてパタン媒体を作製し，その 再生信号を詳細に解析寸ることで，イオンエネルギーによるパタ ン品質の違いを評価した，それにより，高密度化に適したイオン 注入条件を検討した。

エッチングにより作製されたパタン媒体では，走査型電子顕微 鏡 $(\mathrm{SEM})$ や透過型電子顕微鏡 (TEM) などにより比較的容易に パタン形状を評価することが可能である. 一方，イオン注入によ

*1 現所属 : HGST ジャパン日本研究所
り作製されたパタン媒体では，媒体の物理的な形状を変化させる ことなく磁気的なパタンを作製するため, パタン形状の評価が難 しい. 磁気力顕微鏡 $(\mathrm{MFM})$ により磁気的なパタン形状を評価す ることは可能であるが, 数 $\mathrm{nm}$ の微小な違いを評価するには分解 能が十分とは言えない，したがって，パタン品質を詳細に評価す るには，スピンスタンド等によりパタン媒体の信号を再生し評価 する方法が必須である. そのためには低浮上かつ安定したへッド 浮上性を確保する必要があり, まずベースとなる媒体の表面が十 分に平坦であり，か媒体表面におけるパーティクル等の発生が 十分に抑えられていなければならない.この条件を満たすべース 媒体としては従来型の $\mathrm{CoCrPt}-\mathrm{SiO}_{2}$ 垂直磁気記録媒体が最適であ り，本研究でもこれを用いた．また，パタン品質の評価にはサー ボのプリアンブルパタンを用いた. プリアンブルパタンは単純な ラインアンドスペースのパタンであり, 形状等の違いを評価しや すくパタン品質を比較する上で都合がよいためである.

\section{2. 実験方法}

DC マグネトロンスパッタを用い, ガラス基板上にベースとなる 垂直磁気記録媒体を成膜した. 記録層は $\mathrm{CoCrPt}-\mathrm{SiO}_{2}$ グラニュラ 一磁性層と $\mathrm{CoCrPtB}$ キャップ磁生層の積層膜である. グラニュラ 一磁性層とキャップ磁性層の飽和磁化はそれぞれ $0.61 \mathrm{~T}$ および $0.55 \mathrm{~T}$ であり, 膜厚はそれぞれ $13.2 \mathrm{~nm}$ および $4.4 \mathrm{~nm}$ である. ナノインプリントリソグラフィとエッチングによりベース媒体上 にカーボンマスクを形成し, 窒素イオン $\left(\mathrm{N}_{2}{ }^{+}\right)$を注入することで パタン媒体を作製した. 窒素イオン注入にはアルバック社製イオ ン注入システム IHD を用いた. 本装置はパタン媒体製造専用のイ 
オン注入装置であり，媒体両面 2 枚同時のイオン注入を可能とし ている. TRIM17)18)を用いたイオン注入過程のモンテカルロシミ ユレーション結果を基に, マスクの厚さは本研究で用いた最大の イオンエネルギー $16 \mathrm{keV}$ でもイオンを十分に遮蔽できる $50 \mathrm{~nm}$ と した. マスク除去工程の前後で Polar Kerr 効果測定を実施し， マ スク除去工程による磁気特性の变化がないことを確認した．膜面 垂直方向に外部磁場を印加して作製したパタン媒体を着磁した後, スピンスタンドを用いてプリアンブル信号を再生し自己相関信号 雑音比 (ACSNR) を評価した. さらに, パタン形状を評価するた め, 信号強度の二次元マップを作成した. 二次元マップは，再生 信号をクロストラック方向のヘッド位置を $3.8 \mathrm{~nm}$ ステップで変 えて $300 \mathrm{~nm}$ 程度のトラック幅領域で評価し，その信号強度をダ ウントラック方向とクロストラック方向のそれぞれの位置に対し て等高線を描くようにプロットしたものである. 評価にはトンネ ル磁気抵抗効果 (TMR) ヘッドを用い, ヘッド浮上量は $2 \mathrm{~nm}$, 円板の回転数は $5400 \mathrm{rpm}$, 評価半径位置は $21.8 \mathrm{~mm}$ とした. 評 価半径位置におけるプリアンブルパタンのビット長は $213 \mathrm{~nm}$ で ある.イオンを注入した部分の磁気特性は，マスクを形成してい ない媒体全面に窒素イオンを注入した試料を準備し，試料振動型 磁力計（VSM）を用いて評価した.

\section{3. 結果と考察}

マスクを施していない媒体に対し，イオンエネルギーを 8,12 , 14, $16 \mathrm{keV}$ と変えて窒素イオンを注入し, 磁気特性を評価した. ドーズ量は $2.5 \times 10^{16} \mathrm{ions} / \mathrm{cm}^{2}$ とした. なお, TRIM による計算か ら, イオンエネルギーが $12 \mathrm{keV}$ のときに窒素イオンの平均注入深 さが記録層の膜厚方向の中心位置とほぼ一致する. Fig. 1 に各イオ ン注入条件における媒体の磁化曲線を示寸．イオンエネルギーが 高くなるほど飽和磁化と保磁力が減少している. イオンエネルギ 一が高くなるとイオンはより深く注入され，かつ深さ分布の広が りもより大きくなる. 今回用いたイオンエネルギーの範用ではイ オンエネルギーを高くした方が，窒素イオンが記録層の膜厚方向 全体に広く分布して飽和磁化と保磁力がより小さくなったと考え られる.

次に，上記と同じイオン注入条件でパタン媒体を作製し，プリ アンブルパタンの信号強度と ACSNR を評価した. 信号強度と ACSNRのイオンエネルギ一依存性を Fig. 2(a)に, 比較のため Fig. 1 から求めた飽和磁化 $\left(M_{\mathrm{s}}\right)$ のイオンエネルギ一依存性を Fig. 2(b) に示す. 信号強度は $8 \mathrm{keV}$ から $12 \mathrm{keV}$ までで増加し, それ以上の イオンエネルギーではほぼ一定となった。一方, ACSNR はイオ ンエネルギーが $12 \mathrm{keV}$ のときに最大となり, それ以上のイオンエ ネルギーでは低下した，以前我々は，窒素イオンを注入した部分 の飽和磁化が小さくなるほど信号強度が向上し，かつジッタが低 下して ACSNR が向上することを報告した ${ }^{15)}$. 今回 $12 \mathrm{keV}$ 以下 で作製した媒体では，イオンを注入した部分の飽和磁化が小さく なると信号強度が増加し ACSNR も向上していることから, 前報 と同様の結果と言える. 一方, $12 \mathrm{keV}$ 以上で作製した媒体では, イオンを注入した部分の飽和磁化が小さくなっているにも関わら

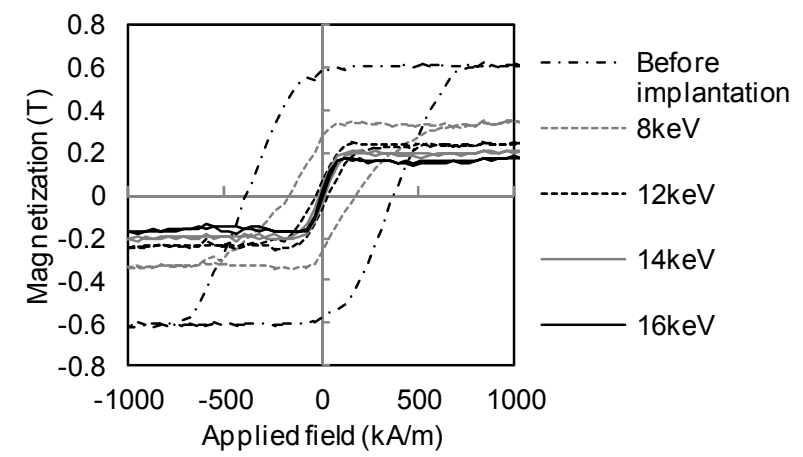

Fig. $1 \quad M$ - $H$ curves before and after nitrogen ion implantation with ion energies of $8,12,14$, and $16 \mathrm{keV}$ on media without a mask.

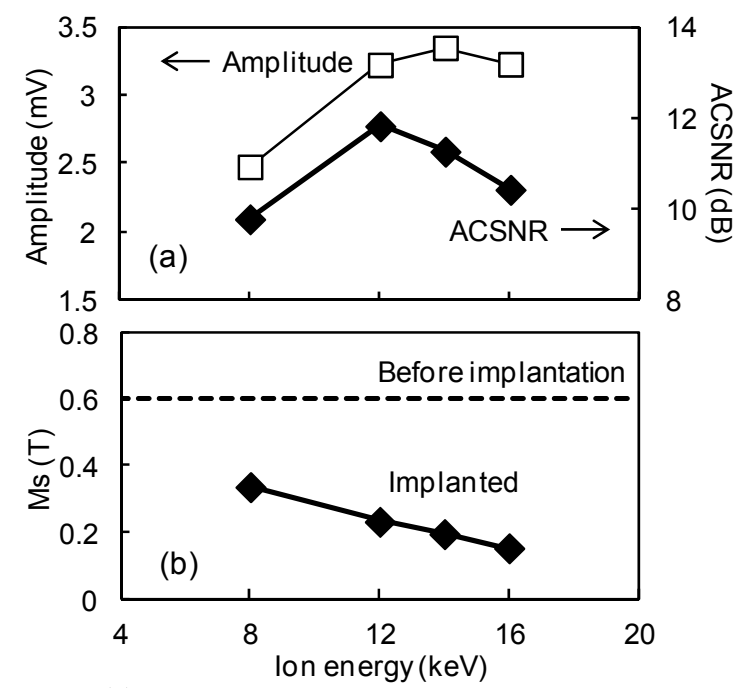

Fig. 2 (a) Amplitude and ACSNR of preamble signal, and (b) $M_{\mathrm{s}}$ of ion-implanted region as a function of ion energy for patterned media fabricated by nitrogen ion implantation.

ずACSNR が低下した．ただし，以前の報告はイオンエネルギー が $10 \mathrm{keV}$ 以下での結果であり, 今回 ACSNR が劣化したのはイ オンエネルギーがより高い場合の結果となる. $12 \mathrm{keV}$ 以上では信 号強度はほぼ一定であったことから, ACSNR の低下はノイズが 増加したことによるものである. イオンエネルギーが高くなる とイオンの分布も変化するが，その分布の変化がパタン品 質に悪影響を及ぼし，ノイズが増加したものと考えられる.以 降, このノイズ増加の原因について解析していく.

イオンエネルギーがパタンの品質に与える影響を評価す るため, $8 \mathrm{keV}$ および $16 \mathrm{keV}$ で作製したパタン媒体につい て，プリアンブル信号強度の二次元マップを作成した。作 成した二次元マップを Fig. 3(a)および(b)に示す. イオンエ ネルギーが低い $8 \mathrm{keV}$ に比べ, イオンエネルギーが高い 16 $\mathrm{keV}$ はパタン形状の摇らぎが大きくなっている. 得られた 二次元マップからマスクを施した部分のパタン形状を測長 した結果を Table 1 に示す. なお, ここでのパタン幅は信 号強度が $0 \mathrm{mV}$ となる点での幅をとっており Fig. 3 の見か けの幅に対応した数值となるが，半值幅ではないため幅の 絶対值に関しては必ずしも正確とは言えない.しかしなが ら, パタン幅の標準偏差やパタン中心位置の標準偏差に関 


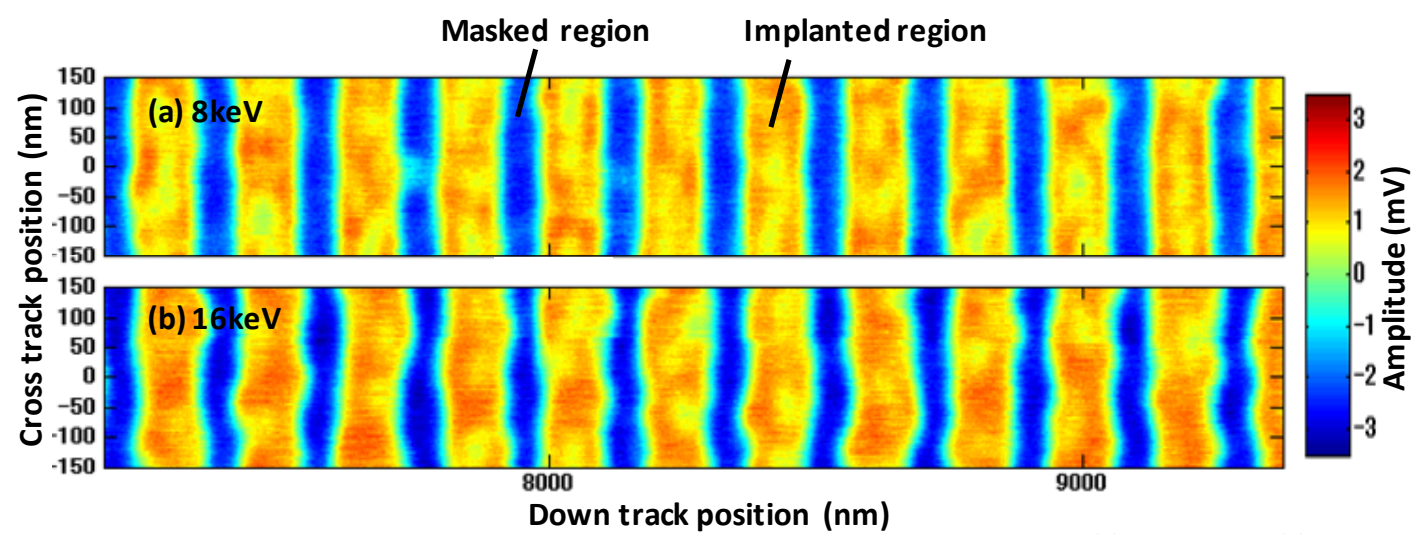

Fig. 3 2D-maps of signal amplitude for preamble pattern fabricated with ion energies of (a) $8 \mathrm{keV}$ and (b) $16 \mathrm{keV}$.

Table 1 Pattern sizes obtained from 2D-maps of preamble signal amplitude.

\begin{tabular}{|c|c|c|c|}
\hline \multirow{2}{*}{ Ion energy $(\mathrm{keV})$} & \multicolumn{2}{|c|}{ Pattern width $(\mathrm{nm})$} & \multirow{2}{*}{$\begin{array}{c}\text { Standard deviation of } \\
\text { pattan center position }(\mathrm{nm})\end{array}$} \\
\cline { 2 - 3 } & Average & Standard deviation & 1.3 \\
\hline 8 & 78 & 4.3 & 2.7 \\
\hline 16 & 77 & 8.4 & \\
\hline
\end{tabular}

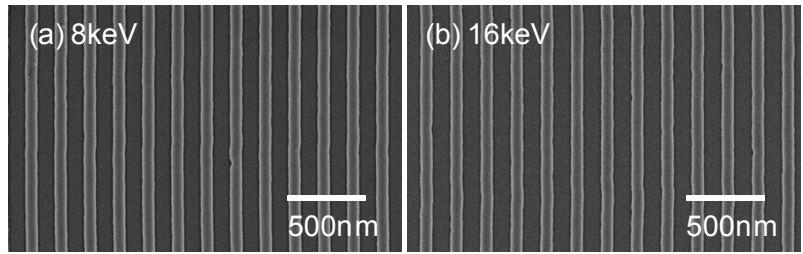

Fig. 4 SEM top-view images of mask for preamble pattern after nitrogen implantation with ion energies of (a) $8 \mathrm{keV}$ and (b) $16 \mathrm{keV}$.

Table 2 Mask sizes obtained from SEM top-view images for preamble pattern after nitrogen ion implantation.

\begin{tabular}{|c|c|c|}
\hline \multirow{2}{*}{ Ion energy $(\mathrm{keV})$} & \multicolumn{2}{|c|}{ Mask width (nm) } \\
\cline { 2 - 3 } & Average & Standard deviation \\
\hline 8 & 79.3 & 0.2 \\
\hline 16 & 79.0 & 0.3 \\
\hline
\end{tabular}

しては，パタンの相対的な位置ずれを反映した数值であり 議論できる. パタン幅の標準偏差が $8 \mathrm{keV}$ に比べ $16 \mathrm{keV}$ ではおよそ 2 倍の大きさになっており，パタンの中心位置 のばらつきも同様に約 2 倍になった。 パタンの中心位置の ばらつきが大きくなるとジッタが増加するため, イオンエ ネルギーが高い場合に ACSNR が劣化したのは，このパタ ン形状の摇らぎによるものであることがわかる. それでは, イオンエネルギーが高くなるとなぜパタン形状の摇らぎが 大きくなったのか. 以降，その原因を考察する.

パタンの形状はマスクの形状を反映したものであるため, イオンエネルギーが高い場合にマスクが何らかのダメージ を受けたとしたら, パタンの形状に影響すると考えられる. そこで，イオン注入後のマスクの形状を SEM により評価 した. Fig. 4(a)および(b)に $8 \mathrm{keV}$ および $16 \mathrm{keV} て ゙$ 窒素イ

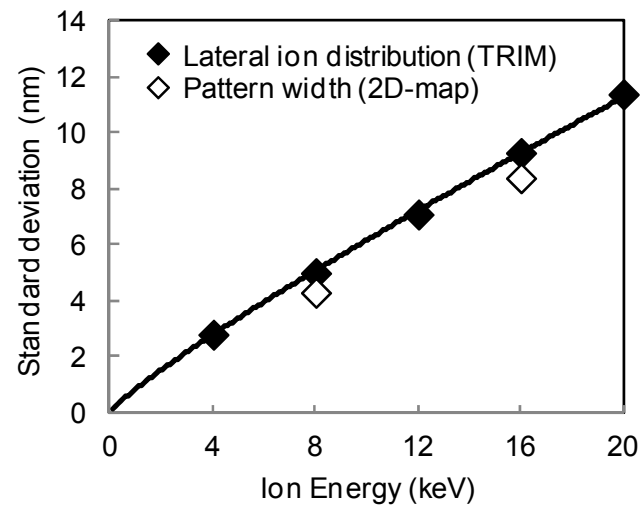

Fig. 5 Standard deviations of lateral ion distribution calculated by TRIM and pattern width obtained from 2D-maps of preamble pattern.

オンを注入した後のマスクの平面 SEM 像を, Table 2 に SEM 像から測長したマスクの形状を示す. マスク形状はイ オンエネルギーにはよらず，マスク幅の標準偏差の值は信 号強度の二次元マップから得られたパタン幅の標準偏差の 值の $1 / 10$ 以下の小さな值となった。すなわち, パタン形状 の摇らぎはマスクの形状によるものではない.

イオン注入において，注入されたイオンは深さ方向に移 動するだけでなく, 面内方向にも散乱されて移動する. し たがって，一部のイオンは面内方向に散乱されてマスクさ れた部分にも分布することになる.この面内方向のイオン の散乱の影響により，ビットパタン媒体のドットサイズの ばらつきが大きくなる ${ }^{11)}$ ，あるいはドットサイズが小さく なる12) といった報告例があり，本報の媒体でもこのイオン の面内方向の散乱が影響してパタン品質が劣化した可能性 が考えられる，そこで，TRIM によりパターニングに用い た媒体と同じ記録層の構造と組成を仮定して注入された窒 
素イオンの分布を計算し, 面内方向分布の標準偏差を求め た. 結果を Fig. 5 に示す. Fig. 5 には信号強度の二次元マ ップから求めたパタン幅の標準偏差も併せて示した. 窒素 イオンの面内方向分布の標準偏差はイオンエネルギーが高 くなるほど大きくなり, その值は信号強度の二次元マップ から求めたパタン幅の標準偏差とほぼ同じ值となった。面 内方向に散乱した一部の窒素イオンがマスクを施した部分 に侵入してパタン形状を乱したことを示しており, 以下の ような現象と考えることができる. 面内方向の散乱により マスク端部からマスクの下にイオンが侵入した領域では, 注入された元素の密度がマスク端部からマスク中心部に向 かって徐々に減少する。 そのため, この領域は磁気特性が 徐々に変化する遷移領域となる. パタン形状の乱れは磁区 構造の乱れであるため, 実験結果はこの遷移領域の磁区構 造が乱れていることを示している.今回作製した媒体では, イオンを注入した部分は完全には非磁性化されておらず磁 化が残っているが，この磁化はマスクによってイオン注入 が遮られた領域の磁化と磁気的に相互作用するため, その 相互作用の影響によりパタン端部の遷移領域の磁区構造が 乱れていると考えられる. イオンの面内方向の散乱の大き さは Fig. 5 に示した通りイオンエネルギーが高くなるほど 大きくなるため, イオンエネルギーが高くなるほど磁気特 性の遷移領域の幅が大きくなり，パタン形状の摇らぎが大 きくなったものと考えられる.さらに Fig. 3 の二次元マッ プを詳細に見ると, イオンを注入した部分の中において信 号強度に多少のばらつきが見られた. 本研究の媒体はイオ ンを注入した部分に磁化が残っており, その磁化が多磁区 となったことで信号強度がばらついた可能性が考えられる。 以前, イオンを注入した部分に残った磁化が大きいほどジ ッタが増加することを報告したが 15), 今回見られた信号強 度のばらつきが関係して可能性も考えられる.ただし, Fig. 3 の $8 \mathrm{keV}$ と $16 \mathrm{keV}$ の結果を比較すると, 信号強度のば らつきに明確に差が出ているわけではなく, 今後さらなる 解析が必要と言える。

信号品質の劣化を防ぐためには，パターニングに用いる イオンのエネルギーを低くしてパタン形状の摇らぎを抑え る必要がある.ただし, Fig. 1 およびFig. 2 で示したよう に，イオンエネルギーを単純に低くしただけでは, 磁化低 減が不十分となり信号品質が劣化してしまう。したがって, 信号品質向上のためには, 低イオンエネルギー化と磁化低 減の両立が必要である。低イオンエネルギー化によって磁 化低減が不十分となる原因は, イオンの注入深さが浅くな り，記録層全体にイオンが分布しなくなるためである。そ のため, イオンの注入深さが浅くなっても記録層全体にイ オンを分布させるには, 記録層を薄くすることが効果的で ある.ただし, 高記録密度化のため記録層を薄膜化して信 号品質の向上を進めていくと, 本研究で用いたような従来 型の $\mathrm{CoCrPt}_{-} \mathrm{SiO}_{2}$ 垂直磁気記録媒体をべースとしたパタン媒体で は, 将来的に熱安定性が不十分となってくる可能性がある. 本研
究で用いた窒素イオン注入は, $\mathrm{Co} / \mathrm{Pd}$ および $\mathrm{Co} / \mathrm{Pt}$ 多層膜, $\mathrm{L} 10$ FePt 規則合金など, 結晶磁気異方性の大きな磁性膜に対するパタ 一ニングにも有効であることが報告されていることから 2),11,12)，こ れらの磁生膜を用いることで記録層の薄膜化による高い信号品質 と熱安定性の両立が可能と考えられる. 例えば, ビットパタン媒 体でドット密度 $2.5 \mathrm{~Tb} / \mathrm{in}^{2}$ を想定した場合, 六方晶型のドット配列 でドットピッチは $17.3 \mathrm{~nm}$ であり, マスクの開口率を $35 \%$ と仮定 するとマスクの直径は $11.4 \mathrm{~nm}$ となる. この場合, イオンの散乱 による影響を $2 \mathrm{~nm}$ 程度に抑えることができれば, $8 \mathrm{~nm}$ 程度のド ットの直径を実現できる. Fig. 5 の結果から, イオンの散乱による 影響はイオンの面内分布の標準偏差から見積もることが可能であ り， $\mathrm{Co} / \mathrm{Pd}$ 多層膜を仮定した場合，イオンエネルギーを $3 \mathrm{keV}$ 以 下にすればイオンの散乱による影響は $2 \mathrm{~nm}$ 以下になると計算さ れる. $3 \mathrm{keV}$ の場合, イオンの平均注入深さは約 $4 \mathrm{~nm}$ と計算され, 膜厚 $8 \mathrm{~nm}$ 程度のものをパターニング可能となる. また, マスクに カーボンを仮定すると, $3 \mathrm{keV}$ の窒素イオンを遮蔽するのに必要 な膜厚は $16 \mathrm{~nm}$ と計算され, マスクのアスペクト比は 1.5 程度で 十分加工が可能と言える.

\section{4. まとめ}

窒素イオン注入を用いたパタン媒体作製技術において, 高密度 化に適したイオン注入条件を検討寸るため, イオンエネルギーに よるパタン品質の変化を評価した. イオンエネルギーが $8 \mathrm{keV}$ から $16 \mathrm{keV}$ の範囲では, イオンを注入した部分の飽和磁化はイオンエ ネルギーが高いほど小さくなったが, プリアンブル信号の ACSNR は $12 \mathrm{keV}$ で最大となり, イオンエネルギーがさらに高くなると劣 化した. $8 \mathrm{keV}$ および $16 \mathrm{keV}$ で作製したパタン媒体のプリアンブ ル信号強度の二次元マップを作成したところ，イオンエネルギー の低い $8 \mathrm{keV}$ に比べ, イオンエネルギーの高い $16 \mathrm{keV}$ ではパタン 形状の摇らぎが大きくなり, そのために信号品質が劣化したこと がわかった. 窒素イオンの面内方向分布の標準偏差を計算し たところ, その值は信号強度の二次元マップから求めたパ タン幅の標準偏差とほぼ同じ值となった。このことから, イオンの面内方向の散乱によりマスクを施した部分にイオ ンが侵入することで, パタン端部に磁気特性が徐々に変化 する遷移領域が形成され，イオンを注入した部分に残った 磁化の影響により，その遷移領域の磁区構造が乱れたもの と考えられる. 信号品質向上のためにはイオンエネルギー を低くしてイオンの面内方向の散乱を抑える必要がある. そして，低いイオンエネルギーでも磁化を十分に低減する ため, 記録層厚を薄くする必要がある.

謝辞 本研究の一部は（独）新エネルギー・産業技術総合 開発機構の委託研究「超高密度ナノビット磁気記録技術の 開発（グリーン IT プロジェクト）」の一環として実施され た. 


\section{References}

1) C. Chappert, H. Bernas, J. Ferré, V. Kotter, J. P. Jamet, Y. Chen, E. Cambril, T. Devolder, F. Rousseaux, V. Mathet, and H. Launois, Science, 280, 1919 (1998).

2) B. D. Terris, D. Weller, L. Folks, J. E. E. Baglin, and A. J. Kellock, J. Appl. Phys., 87, 7004 (2000).

3) O. Hellwig, D. Weller, A. J. Kellock, J. E. E. Baglin, and E. E. Fullerton, Appl. Phys. Lett., 79, 1151 (2001).

4) P. Warin, R. Hyndman, J. Glerak, J. N. Chapman, J. Ferré, J. P. Jamet, V. Mathet, and C. Chappert, J. Appl. Phys., 90, 3850 (2001).

5) M. Abes, J. Venuat, D. Muller, A. Carvalho, G. Schmerber, E. Beaurepaire, A. Dinia, and V. Pierron-Bohnes, J. Appl. Phys., 96, 7420 (2004).

6) E. Suharyadi, T. Kato, S. Tsunashima, and S. Iwata, IEEE. Trans. Magn., 42, 2972 (2006).

7) F. Albertini, L. Nasi, F. Casoli, S. Fabbrici, P. Luches, G. C. Gazzadi, A. di Bona, P. Vavassori, S. Valeri, and S. F. Contri, J. Appl. Phys., 104, 053907 (2008).

8) T. Kato, S. Iwata, Y. Yamauchi, S. Tsunashima, K. Matsumoto, T. Morikawa, and K. Ozaki, J. Appl. Phys., 105, 07C117 (2009).

9) J. Yasumori, Y. Sonobe, S. J. Greaves, and H. Muraoka, IEEE. Trans. Magn., 45, 3703 (2009).

10) M. Aniya, A. Shimada, Y. Sonobe, K. Sato, T. Shima, K. Takanashi, S. J. Greaves, T. Ouchi, and T. Homma, IEEE. Trans. Magn., 46, 2132 (2010).

11) A. Ajan, K. Sato, N. Aoyama, T. Tanaka, Y. Miyaguchi, K. Tsumagari, T. Morita, T. Nishihashi, A. Tanaka, and T. Uzumaki, IEEE. Trans. Magn., 46, 2020 (2010).

12) K. Sato, A. Ajan, N. Aoyama, T. Tanaka, Y. Miyaguchi, K. Tsumagari, T. Morita, T. Nishihashi, A. Tanaka, and T. Uzumaki, J. Appl. Phys., 107, 123910 (2010).

13) T. Hinoue, T. Ono, H. Inaba, T. Iwane, H. Yakushiji, and A. Chayahara, IEEE. Trans. Magn., 46, 1584 (2010).

14) E. Suharyadi, D. Oshima, T. Kato, and S. Iwata, J. Appl. Phys., 109, 07B771 (2011).

15) T. Hinoue, K. Ito, Y. Hirayama, T. Ono, and H. Inaba, $J$. Appl. Phys., 109, 07B907 (2011).

16) D. G. Merkel, L. Bottyán, F. Tanczikó, N. Nagy, G. Vértesy, J. Waizinger, and L. Bommer, J. Appl. Phys., 109, 124302 (2011).

17) J. P. Biersack and L. Haggmark, Nucl. Instrum. Meth. Phys. Res., 174, 257 (1980).

18) J. F. Ziegler, http://www.srim.org/.

2012年1月16日受理，2012年5月17日採録 